\title{
VOLATILITY IN STOCK RETURN SERIES OF VIETNAM STOCK MARKET
}

\author{
Vo Xuan Vinh, Nguyen Thi Kim Ngan \\ University of Economics Ho Chi Minh City \\ (Manuscript Received on April 04 ${ }^{\text {th }}$, 2011, Manuscript Revised September 21 ${ }^{\text {st }}$, 2011)
}

ABSTRACT: This paper studies the features of the stock return volatility using GARCH models and the presence of structural breaks in return variance of VNIndex in the Vietnam stock market by using the iterated cumulative sums of squares (ICSS) algorithm. Using a long-span data, GARCH and GARCH in mean (GARCH-M) models seems to be effective in describing daily stock returns' features. About structural breaks, when applying ICSS to standardized residuals filtered from GARCH $(1,1)$ model, the number of volatility shifts significantly decreases in comparison with the raw return series. Events corresponding to those breaks and altering the volatility pattern of stock return are found to be country-specific. Not any shifts are found during global crisis period. Further evidence also reveals that when sudden shifts are taken into account in the GARCH models, volatility persistence remarkably reduces and that the conditional variance of stock return is much affected by past trend of observed shocks and variance.

Our results have important implications regarding advising investors on decisions concerning pricing equity, portfolio investment and management, hedging and forecasting. Moreover, it is also helpful for policy-makers in making and promulgating the financial policies.

Keywords: ARCH/ GARCH, ICSS algorithm, break points, sudden changes

\section{INTRODUCTION}

Volatility is a fundamental concept in the discipline of finance. Considerable volatilities have been found in the past few years in mature and emerging financial markets worldwide. As a proxy of risk, modelling and forecasting stock market volatility has become the subject of vast empirical and theoretical investigations over the past decades by academics and practitioners. Substantial changes in the volatility of financial market returns are capable of having significant effects on risk averse investors, on consumption patterns, corporate capital investment decisions, leverage decisions and other business cycle. Volatility forecasts of stock price are crucial inputs for pricing derivatives as well as trading and hedging strategies. Therefore, it is important to understand the behavior of return volatility.

In addition to return volatility, some relevant problems attracting much interest of researchers have been whether or not major events may lead to sudden changes in return volatility and how unanticipated shocks will affect volatility over time. Concerning these 
factors, persistence term should be considered. The persistence in volatility is a key ingredient for accurately predicting how events will affect volatility in stock returns and partially determines stock prices. Poterba and Summers (1986) showed that the extent to which stockreturn volatility affects stock prices (through a time-varying risk premium) depends critically on the permanence of stocks to variance. Hence, the degree to which conditional variance is persistent or permanent in daily stock-return data is an important economic issue.

ARCH models proposed by Engle and Bollerslev (1982) and generalized by Bollerslev (1986) and Taylor (1986) have been proved to be sufficient in capturing properties of time-varying stock return volatility as well as volatility persistence. Literature has found many evidences in supporting the capability of GARCH models in volatility estimation (Akgiray (1989) and Pagan, Adrian R. et al. (1989)) rather than other non-GARCH models. Since the introduction of simple GARCH models, a huge number of extensions and alternative specifications such as GARCH in mean (GARCH-M), Threshold GARCH (Glosten, Jagannathan et al. (1993)), has been proposed in attempt to better capture the characteristics of return series. Meanwhile, a procedure based on an iterated cumulative sums of squares (ICSS) by Inclan and Tiao (1994) is commonly used to detect number of (significant) sudden changes in variance in time series, as well as to estimate the time points and magnitude of each detected sudden changes in the variance.

While studies on stock markets in mature and emerging markets are widely available, so far not many researches have focused on Vietnam. Although being set up much later than many countries in the world, Vietnam stock market has been growing rapidly. Therefore, main objective of this paper is to investigate and to model the characteristics of stock return volatility in Vietnam stock market. The Generalized Autoregressive Conditional Heteroscedasticity $(\mathrm{GARCH}(\mathrm{p}, \mathrm{q}))$ model is used to capture the nature of volatility; GJG model (or TGARCH) and GARCH-in-mean (GARCH-M) are for examining leverage effects and risk - return premium respectively. Meanwhile, a procedure based on iterated cumulative sums of squares (ICSS) is used to detect number of (significant) sudden changes in variance in time series, to estimate the time points and magnitude of each detected sudden changes in the variance. Major events surrounding the time points of increased volatility are also analyzed. At the same time, the linkage between volatility shifts in Vietnam stock market with impacts from global crisis in US in 2008 is also mentioned. These detected volatility regimes are then included in the standard GARCH model to calculate the "true" estimate of volatility persistence.

The remainder of this paper is organized as follows: Section 2 presents a brief literature review. Section 3 describes the adopted econometric methodology. The data description

\section{Trang 6}


and empirical results are then reported in Section 4. Summary and concluding remarks are presented in the last Section.

\section{LITERATURE REVIEW}

\subsection{Common characteristics of return} volatility in the stock market

Many studies have documented evidence showing that financial time series have a number of important common features to much financial data such as volatility clustering, leptokurtosis and asymmetry. The studies of Mandelbrot (1963), Fama (1965) and Black (1976) highlighted volatility clustering, leptokurtosis, and leverage effects characteristics of stock returns. Baillie and DeGennaro (1990) and Poon and Taylor (1992) investigated the dynamics of expected stock returns and of volatility in the US and UK stock markets respectively and found out clustering, predictability and persistence in conditional volatility in these markets. These common characteristics of stock returns series also continued to be discovered in many following researches. And recently, Emenike (2010) has found out the features as volatility clustering, leptokurtosis and leverage effects when the author examined the volatility of stock market returns in Nigeria Stock Exchange (NSE).

\subsection{Volatility models suitable to the stock}

\section{return characteristics}

To capture the volatility characteristics in financial time-series, several models of conditional volatility have been proposed. A popular class of model was first introduced by
Engle (1982). Engle (1982) proposed to model time-varying conditional variance with AutoRegressive Conditional Heteroskedasticity $(\mathrm{ARCH})$ processes using squared lagged values of disturbances. This was later generalized by Bollerslev (1986) to GARCH (generalized $\mathrm{ARCH}$ ) model. However, both the ARCH and GARCH models fail to model the leverage effect. To fulfill this requirement, many nonlinear extensions of GARCH have been proposed. Some of the models include exponential GARCH (EGARCH) originally proposed by Nelson (1991), GJR-GARCH model (or also known as Threshold GARCH (TGARCH)) introduced by Glosten, Jagannathan et al. (1993) and Zakoian (1994). Moreover, ARCH-M specification was also suggested by Engle, Lilien et al. (1987) to capture relationship between risks and returns.

Hamilton, Susmel. et al. (1994) found that $\mathrm{ARCH}$ effects were presented when the stock returns series were observed at a high frequency (daily or weekly returns). Bekaert and Harvey (1997) examined thoroughly the behaviour of the volatility of stock indexes returns in emerging markets. They found the volatility difficult to model in this context since each country exhibited a specific behaviour. F.Lee, Chen et al. (2001) used GARCH and EGARCH models for daily returns of Shanghai and Shenzhen index series over 1990 to 1997 and pointed out evidence of time-varying volatility, high persistence and predictability of volatility. In addition, no relationship between expected returns and expected risks was also 
reported as a result of detecting GARCH-M model. Also, Alberga, Shalit et al. (2008) characterized a volatility model by analyzing Tel Aviv Stock Exchange (TASE) indices using various GARCH models like EGARCH, GJR and APARCH. Their results showed that the asymmetric GARCH model with fat-tailed densities improved overall estimation for measuring conditional variance. Similarly, by utilizing GARCH-type models for daily data from Egypt (CMA General index) and Israel (TASE-100 index) markets during period from 1997 to 2007, Floros (2008) concluded that simple GARCH model, as well as EGARCH, TGARCH, and so on could characterize daily returns and that the fluctuation of risk and return were not necessarily on the same trend.

\subsection{Identification of breakpoints in} volatilities and influence of the regime changes

Relevant to stock market volatility, there are many works aimed at identifying the points of change in a sequence of independent random variables. Many authors have found that when the regime changes were taken into account, the above-mentioned highly persistent ARCH/GARCH effects were reduced. Lamoureux and Latrapes (1990) were among the first to study the consequences of jumps in the unconditional variance when the time series is conditionally heteroscedastic. Their paper pointed out that the standard GARCH model's parameters when no regime shifts in variance were augmented were overstated and not reliable. For lack of a methodology such as
ICSS algorithm, time point detection in sudden variance change was conducted by dividing the study periods into equally spaced, nonoverlapping intervals, within which the variance might be different. A relatively recent approach to test for volatility shifts was Inclan and Tiao (1994)'s iterative cumulative sums of squares (ICSS) algorithm. This algorithm allows for systematically detecting multiple breakpoints in variance of a series of independent observations in an iterative way. Results gained from the ICSS algorithm for moderate size (i.e., 200 observations and beyond) was comparable to those obtained by a Bayesian approach or by likelihood ratio tests. According to them, this algorithm could also be used for time series models. By applying the ICSS algorithm to residuals of autoregressive processes, obtained results were similar to those gained from ICSS algorithm to sequences of independent observations. Following Inclan and Tiao (1994), clear effects of regime changes gained from ICSS algorithm on volatility of stock market return and reduction in highly persistent volatility of stock return were presented in the papers of Aggarwal, Inclan et al. (1999), Susmel (2000), Malik and Hassan (2004), Malik, Farooq et al. (2005), Wang and Moore (2009), and Long (2008).

\subsection{Events related to regime changes}

Many papers concerned about whether global or local events were more important in making major shifts in variance of stock return and whether these events tended to be social, political or economic. Aggarwal, Inclan et al.

\section{Trang 8}


(1999)'s empirical work found that high volatility periods were associated with important political, social and economic events in each country rather than global events and that important political events tended to be corresponding to sudden changes in volatility. Aggarwal, Inclan et al. (1999)'s findings were the same as those discovered by Bekaert and Harvey (1997) and Susmel (1997), and Bailey and Chung (1995) respectively. Bacmann and Dubois (2002) examined stock market indexes returns of Argentina, Mexico, Malaysia, Philippines, South Korea, Taiwan and Thailand from 01/01/1988 until 05/01/2001 and had similar conclusion that the jumps were country specific and could be diversified. In recent paper surveying Vietnam stock market, Long (2008) proved that detected regime changes seemed to coincide with the changes in the stock market operating mechanism, in the financial market opening for foreign investors, or in political events around that time.

Contrary to the above findings, after studying five major Down Jones stock indexes in the overall US market, the conclusion drawn from the research of Malik and Hassan (2004) was that most volatility breaks were associated with global events rather than sector-specific news. Hammoudeh and Li (2006) also presented the same viewpoint about the dominance of major global events.

\subsection{Differences in periods before and after} economic recession?

Of all events studied by some authors, impacts of crises on volatility changes of stock return has still remained a large concern of many investors and researchers. Fernandez (2006) analyzed whether the Asian crisis in Thailand in July 1997 and the terrorist attacks of September 11 caused permanent volatility shifts in the world stock markets. Both ICSS algorithm and wavelet-based variance analysis were used to detect structural breaks in volatility during 1997-2002 on eight Morgan Stanley Capital International (MSCI) stock indices. The final results showed that all indices presented breakpoints around the Asian crisis, but only Europe appears to have been affected around the days following the 9/11 attacks. Also, with the same method - ICSS algorithm, Wang and Moore (2009) proved that the evolution of emerging stock markets, exchange rate policy changes and financial crises seemed to cause sudden changes in volatility. These papers implied real influence of crises on stock markets despite at different levels.

\subsection{Overstatement of ICSS algorithm in} raw returns series

Despite being used widely in many works, recent literature has shown that the ICSS algorithm tends to overstate the number of actual variance shifts. This originated from ICSS algorithm proposed by Inclan and Tiao (1994) aiming to detect structural breaks in the unconditional variance of time-series. This algorithm requires the time-series to be independent while stock returns are known to violate this assumption because these series are conditionally heteroscedastic. Hence, in 
Bacmann and Dubois (2002)'s paper, they pointed out one way to circumvent this problem. That was by filtering the return series by a GARCH $(1,1)$ model, and applying the ICSS algorithm to the standardized residuals obtained from the estimation. Filtering returns through GARCH $(1,1)$ model helped partly remove both serial correlation and $\mathrm{ARCH}$ effects in return series. Therefore, by applying this procedure (and an alternative one they proposed) to stock market indices of ten emerging markets, Bacmann and Dubois obtained results that differed considerably from Aggarwal, Inclan et al. (1999). That was "jumps in variance are less frequent than previously believed". The findings gained from Bacmann and Dubois (2002)'s research was then applied by some other authors like Fernandez (2006) and Long (2008), of which Fernandez (2006) compared results from using ICSS to both raw and filtered returns and also concluded that the number of shifts substantially decreased in case of filtered return.

\section{RESEARCH METHODS}

Firstly, GARCH models are estimated and compared to identify which model is more appropriate in description of the characteristics of the collected data. Model selection is based on Akaike information criterion (AIC) and Schwarz's (1978) Bayesian information criterion (SBIC). Secondly, following Aggarwal, Inclan et al. (1999) and Hammoudeh and Li (2006), shifts in volatility and corresponding events are identified with the iterated cumulative sums of squares (ICSS) algorithm. After that, the two GARCH models are estimated, one conventional (or standard) and the other with dummy variables corresponding to the breakpoints as discovered in the ICSS to check changes in parameters of models if any.

The followings are the methods applied in this paper. Most of them are based on literature of Brooks (2008).

\subsection{ICSS algorithm}

ICSS algorithm was introduced by Inclan and Tiao (1994) to detect sudden changes in variance caused by shocks. Let the $\varepsilon_{\mathrm{t}}$ be a series with zero mean, and an unconditional variance $\sigma_{\mathrm{t}}^{2}$. This time series of interest has a stationary variance over an initial time period until a sudden break takes place. The variance is then stationary until the next sudden change occurs. This process repeats through time, giving a time series of observations with a number of $\mathrm{N}_{\mathrm{T}}$ breakpoints in the unconditional variance along the sample with T observations. Denoted variance for each interval is $\tau_{j}, j=0,1,2 \ldots, N_{T}$ and $1<\kappa_{1}<\kappa_{2}<\ldots<\kappa_{N_{T}}$ is a set of corresponding breakpoints:

$$
\begin{aligned}
\sigma_{t}^{2} & =\tau_{0}^{2} & & 1<t<\kappa_{1} \\
& =\tau_{1}^{2} & & \kappa_{1}<t<\kappa_{2}
\end{aligned}
$$

$=\tau_{N_{T}}^{2} \quad \kappa_{N_{T}}<t<T$

To estimate the number of changes in variance and the time points of each variance

\section{Trang 10}


shift, $C_{k}$ which presents cumulative sum of squares is used. $C_{k}$ is calculated as

$$
C_{k}=\sum_{t=1}^{k} \varepsilon_{t}^{2}, \quad k=1,2, \ldots, \mathrm{T}
$$

Then, the $D_{k}$ statistic is defined as below:

$$
D_{k}=\frac{C_{k}}{C_{T}}-\frac{k}{T}, \quad k=1,2, \ldots, \mathrm{T} \quad \text { With }
$$

$D_{0}=D_{T}=0$

Inclan and Tiao (1994) showed that the plot of $D_{k}$ oscillates around zero for series with homogeneous variance. In contrast, when there is a sudden change or break point, the plot of $D_{k}$ will extend beyond the specified boundaries with high probability. At a known level of probability, critical values are used to identify upper and lower boundaries for variance changes. When the maximum of the absolute value of $D_{k}$ is greater than the critical value, there is a change point.

Let define $\mathrm{k}^{*}$ as the point in time at which the maximum absolute value of $D_{k}$ is reached. Then, if $\quad \max _{k} \sqrt{(T / 2}\left|D_{k}\right|$ (standardized distribution of $D_{k}$ ) at $\mathrm{k}^{*}$ falls outside the predetermined boundaries, $\mathrm{k}^{*}$ is taken as an estimate of the change point. Inclan and Tiao (1994) computed and pointed out critical values of 1.358 being the $95^{\text {th }}$ percentile of the asymptotic distribution of max standardized $D_{k}$. Upper and lower boundaries can be set at + /1.358 .

However, Inclan and Tiao (1994) claimed that using the $D_{k}$ function to find out the multiple break points simultaneously may be questionable due to the "masking effect". Therefore, "an iterative scheme based on successive application of $D_{k}$ to pieces of the series, dividing consecutively after a possible change point is found", is suggested.

In addition, according to Inclan and Tiao (1994), this algorithm can be also included as part of the residual diagnostics for practitioners fitting time series models. Through simulation results, it is showed that when the ICSS algorithm is applied to residuals of autoregressive processes, similar results to those obtained when applying the ICSS algorithm to sequences of independent observation are found.

\subsection{Combination of GARCH model and} sudden changes

Lamoureux and Latrapes (1990) and some other researchers showed that volatility persistence was overestimated when standard GARCH models were applied to a series with underlying sudden changes in variance. Regime shifts should be added into the standard GARCH model to get reliable parameter estimates in the conditional variance equation as follows:

$$
\begin{aligned}
& R_{t}=\phi_{0}+\sum_{i=1}^{k} \phi_{i} X_{i}+u_{t} \\
& u_{t} \sim N\left(0, \sigma_{t}^{2}\right) \\
& \sigma_{t}^{2}=\omega+d_{1} D_{1}+d_{2} D_{2}+\ldots+d_{n} D_{n}+\sum_{i=1}^{q} \alpha_{i} u_{t-i}^{2}+\sum_{i=1}^{p} \beta_{i} \sigma_{t-i}^{2}
\end{aligned}
$$
where

- $D_{1}, D_{2}, \ldots, \mathrm{D}_{\mathrm{n}}$ are a set of dummy variables controlling for regime changes

- $\omega$ is the constant term that stands for the average volatility of the first volatility regime, 
ignoring any effect of past residuals on the conditional variance.

- The coefficients of $D_{1}, D_{2}, \ldots, \mathrm{D}_{\mathrm{n}}$ show how the subsequent regimes' volatility is different from the first regime volatility and how the volatility varies between different regimes.

\section{DATA AND EMPIRICAL RESULTS}

\subsection{Data}

The data employed in this study comprise 2,121 observations of daily closing stock price index, obtained from the website of Hochiminh Stock Exchange (www.hsx.vn). The sample period is from 1 March 2002 to 31 August 2010 which is the most updated data to the time of this study. Since securities trading transactions have been conducted every working day from March 2002 as today instead of trading only once every two working-days, 1 March 2002 is chosen for this article to create synchronization in data. To represent for Vietnam stock market index in this paper, the VNIndex of HOSTC is chosen since HOSTC was launched first and has almost 4 year-longer history than that of HASTC. VNIndex is the value-weighted stock price index of all common stocks traded on the Vietnam official stock exchange.

Table 1 shows the descriptive statistics for daily stock market returns with daily returns computed as $\mathrm{R}_{\mathrm{t}}=\ln \left(\mathrm{P}_{\mathrm{t}} / \mathrm{P}_{\mathrm{t}-1}\right)$, where $\mathrm{P}_{\mathrm{t}}$ is the daily price at time $t$ and $\mathrm{P}_{\mathrm{t}-1}$ is the daily price at time $t-1$.
Table 1. Descriptive statistics of Vietnam stock market's daily stock return

\begin{tabular}{|c|c|}
\hline Index & VNIndex daily return \\
\hline Mean & 0.0004 \\
\hline Median & 0.0000 \\
\hline Maximum & 0.0472 \\
\hline Minimum & -0.0498 \\
\hline Standard Deviation & 0.0163 \\
\hline Skewness & 0.0143 \\
\hline Kurtosis & 4.1443 \\
\hline Jarque-Bera & 115.73 \\
\hline Probability & 0.0000 \\
\hline Observations & 2120 \\
\hline
\end{tabular}

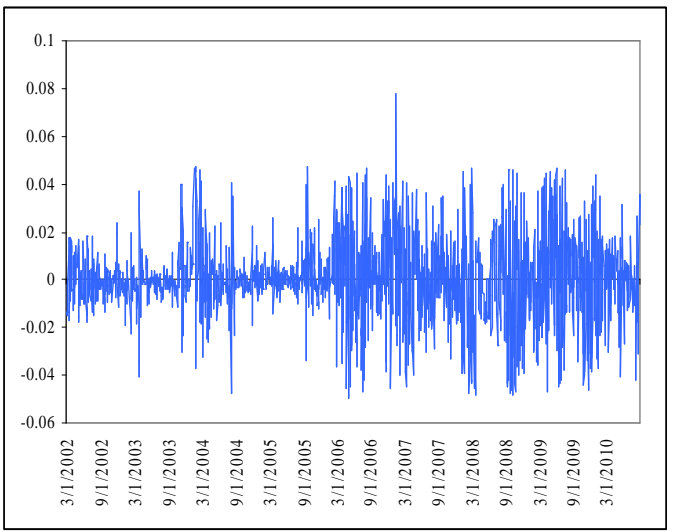

Figure 1. Daily stock return on HOSE

The statistics point out that the daily average returns are positive and depart substantially from normality, evidenced by their high excess kurtosis and asymmetry.

Moreover, autocorrelation and stationarity of Vietnam stock market's return are also checked on the basis of the Ljung-Box (LB) and Augmented Dickey-Fuller (ADF) test statistics. The results showed that there is a significant autocorrelation between stock returns and the

\section{Trang 12}


stock returns series is stationary with the larger absolute value of the test statistic compared with the critical value at $1 \%$. With the mentioned features, it shows clear volatility clustering and seems that the current or past values can provide some predictions about future returns. Figure 1 provides an overview of volatility clustering of daily stock return.

In summary, volatility features of return series are similar to the studies of Mandelbrot (1963), Fama (1965), Black (1976), Baillie and DeGennaro (1990), Poon and Taylor (1992) and recently Emenike (2010).

\subsection{Empirical results}

\subsubsection{Suitable models for stock return series of Vietnam.}

Table 2. Empirical results of different GARCH-family models

\begin{tabular}{|c|c|c|c|c|c|c|c|c|c|}
\hline & $\delta$ & $\omega$ & $\alpha$ & $\beta_{1}$ & $\beta_{2}$ & $\beta_{3}$ & $\gamma$ & AIC & SBC \\
\hline $\operatorname{GARCH}(\mathbf{1}, \mathbf{1})$ & & $\begin{array}{l}\text { 2.64E-06 } \\
(0.000)\end{array}$ & $\begin{array}{l}0.326 \\
(0.000)\end{array}$ & $\begin{array}{l}0.713 \\
(0.000)\end{array}$ & & & & -6.053 & -6.037 \\
\hline $\operatorname{GARCH}(2,1)$ & & $\begin{array}{l}3.06 \mathrm{E}-0 \\
(0.000)\end{array}$ & $\begin{array}{l}0.397 \\
(0.000)\end{array}$ & $\begin{array}{l}0.334 \\
(0.000)\end{array}$ & $\begin{array}{l}0.3089 \\
(0.000)\end{array}$ & & & -6.057 & -6.038 \\
\hline $\operatorname{GARCH}(\mathbf{3 , 1})$ & & $\begin{array}{l}\text { 3.11E-06 } \\
(0.000)\end{array}$ & $\begin{array}{l}0.427 \\
(0.000)\end{array}$ & $\begin{array}{l}0.350 \\
(0.000)\end{array}$ & $\begin{array}{l}0.135 \\
(0.071)\end{array}$ & $\begin{array}{l}0.139 \\
(0.009)\end{array}$ & & -6.053 & -6.030 \\
\hline GARCH-M(1,1) & $\begin{array}{l}3.652 \\
(0.015)\end{array}$ & $\begin{array}{l}2.89 \mathrm{E}-06 \\
(0.000)\end{array}$ & $\begin{array}{l}0.310 \\
(0.000)\end{array}$ & $\begin{array}{l}0.718 \\
(0.000)\end{array}$ & & & & -6.061 & -6.042 \\
\hline GARCH-M(2,1) & $\begin{array}{l}3.9118 \\
(0.008)\end{array}$ & $\begin{array}{l}3.09 \mathrm{E}-06 \\
(0.000)\end{array}$ & $\begin{array}{l}0.345 \\
(0.000)\end{array}$ & $\begin{array}{l}0.529 \\
(0.000)\end{array}$ & $\begin{array}{l}0.159 \\
(0.082)\end{array}$ & & & -6.062 & -6.040 \\
\hline TGARCH(1,1) & & $\begin{array}{l}2.86 \mathrm{E}-06 \\
(0.000)\end{array}$ & $\begin{array}{l}0.290 \\
(0.000)\end{array}$ & $\begin{array}{l}0.7214 \\
(0.000)\end{array}$ & & & $\begin{array}{l}0.0382 \\
(0.187)\end{array}$ & -6.059 & -6.040 \\
\hline
\end{tabular}

Notes: - We report the results from GARCH-type models using the method of maximum likelihood, under the assumption that the errors are conditionally normally distributed.

- $p$-value in the parentheses

\section{GARCH Model}

After testing some models, the result shows that three suitable GARCH models include $\operatorname{GARCH}(1,1), \operatorname{GARCH}(2,1), \operatorname{GARCH}(3,1)$. All parameters of these models are statistically significant at $10 \%$ level. However, only $\operatorname{ARMA}(1,2)$ without $\mathrm{C}$ constant and $\mathrm{GARCH}$ $(2,1)$ with the smallest AIC and SBC seem to be the most suitable model for stock return series of Vietnam stock market.

The sum of the coefficients of GARCH model on the lagged squared error and lagged conditional variance is very close to one. This implies that shocks to the conditional variance are highly persistent (or volatility clustering). In other words, the current level of volatility 
tends to be positively correlated with its level during the immediately preceding periods. They are in consistent with the finding of F.Lee, Chen et al. (2001).

GARCH-M Models: With non-negative conditions for all parameters, only GARCH$\mathrm{M}(1,1)$ and GARCH-M(2,1) are statistically significant at $10 \%$ level. These imply that investors bearing higher risks are compensated by higher returns. With the same criteria for choosing GARCH model, GARCH-M(1,1) is more appropriate. This finding contrasts with F.Lee, Chen et al. (2001)'s study for four China stock exchanges.

TGARCH model: Table 2 shows that asymmetric coefficient $\gamma$ is positive at 0.038 but not statistically significant at $10 \%$ level. The finding shows that there is no difference between the impacts of good and bad news on stocks' return. In other words, response of volatility to positive and negative shocks is symmetric and is in converse trend with volatility of TASE indices in Israel by Alberga, Shalit et al. (2008) and of CMA General index in Egypt by Floros (2008).

In summary, GARCH family is suitable to return volatility of Vietnam stock market and such strong volatility in Vietnam stock market is compensated by high risk premium.

\subsubsection{Identification of break points and} detection of related events

In the following part, we will detect and compare breakpoints in both raw and filtered return series to make clear the overstatement of ICSS when applying to raw data. In addition, events related to sudden changes in filtered data are also analyzed.

\subsubsection{Breakpoints in raw returns}

In this part, ICSS algorithm is applied to raw returns series. Total 23 breakpoints are found and presented in Table 3.

Table 3. Breakpoints detected by ICSS algorithm in the raw returns

\begin{tabular}{|l|l|l||l|l|l|}
\hline No. & \multicolumn{1}{|c|}{ Time period } & \multicolumn{1}{c|}{ Duration } & No. & \multicolumn{1}{c|}{ Time period } & \multicolumn{1}{c|}{ Duration } \\
\hline 1 & $01 / 03 / 2002-29 / 07 / 2002$ & 5 months & 13 & $05 / 10 / 2004-07 / 01 / 2005$ & 3 months \\
\hline 2 & $30 / 07 / 2002-26 / 02 / 2003$ & 7 months & 14 & $10 / 01 / 2005-13 / 01 / 2005$ & 4 days \\
\hline 3 & $27 / 02 / 2003-04 / 03 / 2003$ & 5 days & 15 & $14 / 01 / 2005-25 / 03 / 2005$ & $>2$ months \\
\hline 4 & $05 / 03 / 2003-02 / 04 / 2003$ & 1 month & 16 & $28 / 03 / 2005-10 / 05 / 2005$ & 1.5 months \\
\hline 5 & $03 / 04 / 2003-29 / 04 / 2003$ & 1.5 months & 17 & $11 / 05 / 2005-18 / 05 / 2005$ & 8 days \\
\hline 6 & $05 / 05 / 2003-03 / 12 / 2003$ & 7 months & 18 & $19 / 05 / 2005-16 / 09 / 2005$ & 4 months \\
\hline 7 & $04 / 12 / 2003-19 / 12 / 2003$ & 15 days & 19 & $19 / 09 / 2005-08 / 11 / 2005$ & 1.5 months \\
\hline 8 & $22 / 12 / 2003-19 / 02 / 2004$ & 2 months & 20 & $09 / 11 / 2005-23 / 11 / 2005$ & 15 days \\
\hline 9 & $20 / 02 / 2004-05 / 04 / 2004$ & $>1$ months & 21 & $24 / 11 / 2005-20 / 01 / 2006$ & 2 months \\
\hline 10 & $06 / 04 / 2004-26 / 05 / 2004$ & $>1.5$ months & 22 & $23 / 01 / 2006-23 / 03 / 2006$ & 2 months \\
\hline
\end{tabular}

\section{Trang 14}




\begin{tabular}{|l|l|l|l|l|l|}
\hline 11 & $27 / 05 / 2004-07 / 09 / 2004$ & $>3$ months & 23 & $24 / 03 / 2006-20 / 04 / 2006$ & $<1$ month \\
\hline 12 & $08 / 09 / 2004-04 / 10 / 2004$ & 1 month & 24 & $21 / 04 / 2006-31 / 08 / 2010$ & $>4$ years \\
\hline
\end{tabular}

Through finding breakpoints using raw returns, the shifts/break periods are divided into rather small durations, of which some have only several days while the period having longest duration is just 7 months. It seems that with too short periods of only some days, changes in volatility of the market can not be enough to reflect any reactions of the market to any events as well as reveal any market trends. In addition, it is clear to see that many shifts are not attached to any major information that can be thought to have impacts on the volatility of the stock market returns (such as the establishment of associations). This partly implies the lag or predict/ leak of information from the market. In addition, the most interesting thing here is that no breakpoints/ sudden jumps are found in Vietnam stock market during the period the world market was been suffering from economic crisis. The finding is not similar to the previous researches of Fernandez (2006) and Wang and Moore (2009).

Strong market return volatility occurred on the first months of 2004 and from early 2006 to August 2010. These are consistent with upward trend in stock price volatility in Vietnam stock market during such periods.

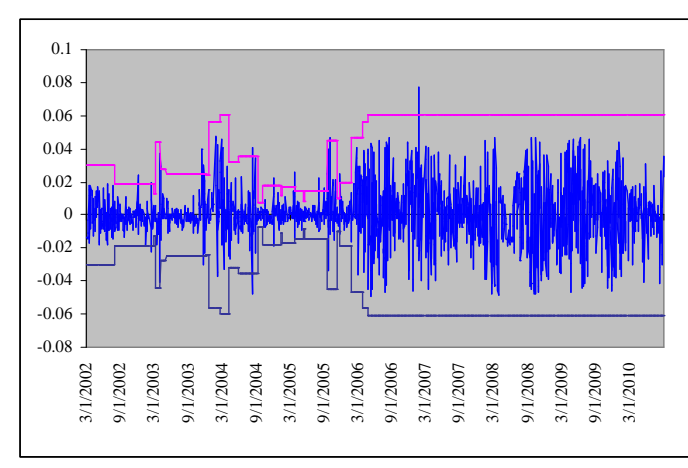

Figure 2. Structural breakpoints in volatility in raw returns

Note: Bands at +/- 3 standard deviation, breakpoints estimated by using the ICSS algorithm.

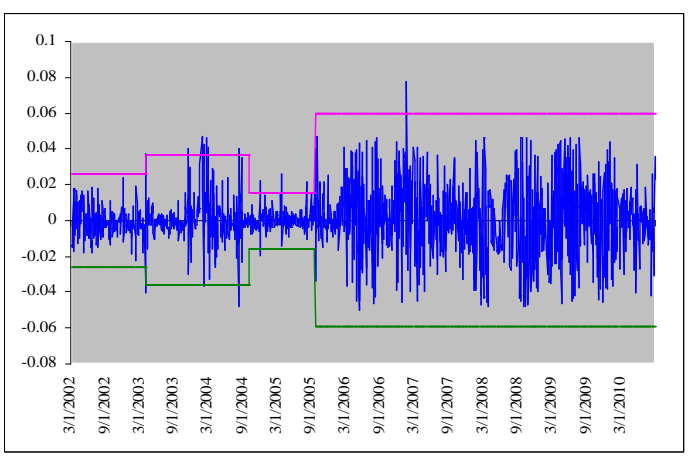

Figure 3. Structural breakpoints in volatility in filtered returns

Note: Bands at +/- 3 standard deviation, breakpoints estimated by using the ICSS algorithm

\subsubsection{Breakpoints in filtered returns}

In this part, ICSS algorithm is then applied to the standardized residuals obtained from $\operatorname{GARCH}(1,1)$ model. The number of found sudden changes is remarkably reduced to only 3 versus 23 breakpoints in the raw return series. The finding implies overstatement of ICSS algorithm in the raw return series and is in 
according with the former conclusions of

Bacmann and Dubois (2002) and Fernandez
(2006). The breakpoints are depicted in Figure 3.

Table 4. Breakpoints detected by ICSS algorithm in the filtered returns

\begin{tabular}{|l|c|l|l|l|}
\hline No. & \multicolumn{1}{|c|}{ Time period } & \multicolumn{1}{|c|}{ Duration } & Daily Mean & STDEV \\
\hline 1 & $01 / 03 / 2002-02 / 04 / 2003$ & 13 months & -0.00107 & 0.008788 \\
\hline 2 & $03 / 04 / 2003-04 / 10 / 2004$ & 18 months & 0.001259 & 0.012081 \\
\hline 3 & $05 / 10 / 2004-16 / 09 / 2005$ & 11 months & 0.000592 & 0.005266 \\
\hline 4 & $19 / 09 / 2005-31 / 08 / 2010$ & 4 years & 0.000429 & 0.019775 \\
\hline
\end{tabular}

It is realized that the duration of each regime is much longer than those detected in the raw returns series. Of all shifts, the last period has the highest volatility and longest duration. Four periods of regime shifts identified by ICSS algorithm contain relevant information that may have influence on the volatility of the stock market and tend to correspond to country-specific notable events as shown in the above table. And the similar conclusion in comparison with the results in the raw returns is that no breakpoints exist during the time when world stock market was facing and suffering from the plump of listed stocks as a consequence of economic downturn.

\subsubsection{General comments on events and} volatility corresponding to sudden change periods detected by ICSS

Volatilities on the stock market are in close relationship with macro-economic contexts, changes in mechanisms and government's policies and regime shifts is not independently separated from these major events. Some major events directly correlate with sudden variance changes in the regime shifts while some events do not. However, it is difficult to point out exactly the causes of sudden changes. These events; hence, are considered contributing factors. Participants in the market may predict appearance of some events or receive information leaks from internal in advance while sometimes they respond with time lag. Therefore, analyzing events attached to certain sudden changes seems to be relative.

Furthermore, when analyzing the relationship between risk and return in separate volatility periods, it is clear that high volatility is not always corresponding to high daily mean in Vietnam stock market. This finding seems to be contrary to the conclusion drawn from GARCH - M model. Nevertheless, the result from GARCH model indicates general trend for the whole research period, not for any particular sub-period.

Another interesting thing is that most volatility breaks are associated with countryspecific events. The result does not mean that global economic recession did not have any impacts on volatility of Vietnam stock market. Its influences on the volatility were gradual and

\section{Trang 16}


did not cause any sudden jumps in variance of stock returns.

4.2.3. Combined GARCH model after including dummies

$$
\begin{array}{rlrl}
R_{t}= & 0.9941 R_{t-1}-0.688 u_{t-1}-0.2955 u_{t-2} & u_{t} \sim N\left(0, \sigma_{t}^{2}\right) \\
& (0.00)^{*} \quad(0.00) & (0.00) & \\
\sigma_{t}^{2}= & 0.000005-0.000002 D_{1}-0.000003 D_{2}+0.000015 D_{3}+0.3143 u_{t-1}^{2}+0.6567 \sigma_{t-1}^{2} \\
& (0.00) & (0.079) & (0.011)
\end{array}
$$

(*): p-value in parentheses

The result shows that the volatility persistence (i.e., $(\alpha+\beta)$ is reduced after dummy variables are combined to the model. This finding is consistent with the earlier findings of Lamoureux and Latrapes (1990), Aggarwal, Inclan et al. (1999) , Malik and Hassan (2004), Wang and Moore (2009). The result implies that persistence of volatility may be misleading or estimation of conditional variance will be less accurately if not taking regime changes into account.

The parameters of regime shifts are very small. These can be explained in the way that major events in the time points of shifts have influences on volatilities of stock returns; however, their effects are not large. This phenomenon also implies current volatility of stock returns mostly depend on past values of shocks - represented by $u_{t-i}^{2}$ - and past values of $\sigma_{t}^{2}$ itself. In other words, stock returns' volatility on Vietnam stock market is much affected by market tendency in previous periods. Indeed, Vietnam stock market has been on improving and developing process,
Three dummies with one constant variable (C) will be used to represent four phases divided by the breakpoints. The modified model is presented as below:

investment activities of market participants have not been professional yet and still been following trend of crowds or been affected by herd psychology and directed by large investors/ price makers.

\section{CONCLUSION}

This paper examined the characteristics of stock returns volatility on Vietnam stock market, using the returns series of VNIndex from March 1, 2002 to August 31, 2010. Some common features of financial time series such as volatility clustering, non-normal and high persistence in variance are found in the whole sample and described by GARCH, GARCH-M models. In addition, time periods of volatility shifts were also detected through the iterated cumulative sums of squares (ICSS) algorithm. The number of breakpoints considerably decreased when filtering return series by GARCH $(1,1)$ model, indicating overstatement of ICSS in raw data. Each regime shift in filtered return combined with many events which were country specific. Nevertheless, it was hard to show exactly which events influenced on certain volatility periods owing 
to time lag or information predictability of investors. Furthermore, an interesting finding was that no shifts were discovered in Vietnam stock market during the world economic downturn, implying that the impacts of the crisis was not large enough to create sudden changes in stock return's variance.

When the standard GARCH model was supplemented with volatility breaks gained from filtered return series, volatility persistence in conditional variance was reduced. Owing to small effects of regime shifts' coefficients, Vietnam stock market was considered to be much affected by market tendency in previous periods. Non - professional of investors, trend of crowds or herd psychology are the factors that can be used to explain for this finding.

The identification and modeling of volatility due to regime changes plays an important role in the successful performance of the stock market. It can assist in advising investors on decisions concerning pricing equity, portfolio investment \& management and hedging. In addition, it can also assist policy-makers in the financial policy making process.

\title{
SỰ BIẾN ĐộNG LỢI NHUẬN CỔ PHIẾU TRÊN THỊ TRƯờNG CHỨNG KHOÁN VIẸT NAM
}

\author{
Võ Xuân Vinh, Nguyễn Thị Kim Ngân \\ Trường Đại Học Kinh Tế Thành Phố Hồ Chi Minh
}

TÓM TÄT: Bài báo này nghiên cưu các đặc điểm của sư biến động lợi nhuận của VNIndex qua việc sủ̉ dụng mô hình GARCH và nghiên cứu sư hiện diện của các điểm gãy cấu trúc trong phuong sai của chuỗi lợi nhuận đó thông qua việc sủ dụng thuật toán ICSS. Sủ dụng dũ liệu trong một khoảng thời gian dài, mô hìn GARCH và GARCH-M tỏ ra hiệu quả trong việc mô tả các đặc điểm của lợi nhuận chứng khoán hàng ngày. Về các điểm gãy cấu trúc, khi áp dụng ICSS cho phần du chuẩn hóa đurợc lọc tù mô hình $\operatorname{GARCH}(1,1)$ thì số luợng các điểm gãy đã giảm đi đáng kể so với khi áp dụng cho chuỗi lợi nhuận thuần túy. Các sụ kiện ứng với các giai đoạn được chia bởi các điểm gãy và làm thay đổi mẫu biến động lọi nhuận chứng khoán mang đặc tính cu thể của quốc gia. Không một sụ thay đổi đột ngột nào trong phuoong sai lợ ;nhuận được tìm thấy trong suốt thời gian xảy ra khủng hoảng toàn cầu. Hơn nưa, bằng chứng cũng cho thấy rằng khi nhũng điểm thay đổi đột ngột đó được kết hợp trong uớc luợng các mô hình GARCH thì mức độ ảnh hưởng của các biến động quá khứ lên các biến động hiện tại bị giảm đi và rằng phuơng sai có điều kiện của lọi nhuận cổ phiếu chịu ảnh huởng nhiều bới xu huớng quá khú của các cú sốc và các phuoong sai trong các giai đoạn truớc đó.

\section{Trang 18}


Kết quả nghiên cứu có ngư ý quan trọng đối với các nhà đầu tu trong việc ra các quyết định liên quan đến việc định giá cổ phiếu, quản lý và đầu tu danh muc, phòng ngùa và dụ báo. Ngoài ra, nó cũng có ích cho các nhà làm chính sách trong việc thực hiện và ban hành các chính sách tài chính.

Tù khóa: ARCH/ GARCH, thuật toán ICSS, điểm gãy, sụ thay đổi đột ngột.

\section{REFERENCE}

[1]. Aggarwal, R., Inclan, C., et al. (1999), Volatility in Emerging Stock Markets, Journal of Financial and Quantitative Analysis, Vol. 34, No.1, pp. 33-55.

[2]. Akgiray, V. (1989), Conditional Heteroscedasticity in Time Series of Stock Returns: Evidence and Forecasts, Journal of Business, Vol. 62, pp. 55-80.

[3]. Alberga, D., Shalit, H., et al. (2008), Estimating stock market volatility using asymmetric GARCH models, Applied Financial Economics, Vol. 18, pp. 12011208.

[4]. Bacmann, J. F. and Dubois, M. (2002), Volatility In Emerging Stock Markets Revisited, London Meeting: European Financial Management Association (EFMA).

[5]. Bailey, W. and Chung, Y. P. (1995), Exchange Rate Fluctuations, Political Risk, and Stock Market Returns: Some Evidence from an Emerging Market, Journal of Finanial and Quantitative Analysis, Vol. 30, pp. 541 - 561.

[6]. Baillie, R. T. and DeGennaro, R. P. (1990), Stock Returns and Volatility, Journal of Financial \& Quantitative Analysis, Vol. 25, No.2, pp. 203-214.
[7]. Bekaert, G. and Harvey, C. R. (1997), Emerging equity market volatility, Journal of Financial Economics, Vol. 43, No.1, pp. 29-77.

[8]. Black, F. (1976), Studies of stock market volatility changes, Proceedings of the American Statistical Association: Business and Economic Statistics Section.

[9]. Bollerslev, T. (1986), Generalized autoregressive conditional heteroskedasticity, Journal of Econometrics, Vol. 31, No.3, pp. 307327.

[10].Brooks, C. (2008), Introductory Econometrics for Finance, Cambridge University Press.

[11].Emenike, K. O. (2010), Modelling Stock Returns Volatility in Nigeria Using GARCH Models, MPRA Paper.

[12]. Engle, R. F. (1982), Autoregressive Conditional Heteroscedasticity with Estimates of the Variance of United Kingdom Inflation, Econometrica, Vol. 50, No.4, pp. 987-1007.

[13]. Engle, R. F. and Bollerslev, T. (1982), Autoregressive Conditional Heteroscedasticity with Estimates of the Variance of United Kingdom Inflation, 
Econometrica, Vol. 50, No.4, pp. 9871007.

[14]. Engle, R. F., Lilien, D. M., et al. (1987), Estimating Time Varying Risk Premia in the Term Structure: the ARCH-M Model., Econometrica, Vol. 55, pp. 391 407.

[15].F.Lee, C., Chen, G.-m., et al. (2001), Stock Returns and Volatility on China's stock markets, The Journal of Financial Research Vol. XXIV, No.4, pp. 523-543.

[16]. Fama, E. F. (1965), The Behavior of Stock-Market Prices, The Journal of Business, Vol. 38, No.1, pp. 34-105.

[17]. Fernandez, V. (2006), The impact of major global events on volatility shifts: Evidence from the Asian crisis and 9/11, Economic systems, Vol. 30, No.1, pp. 79-97.

[18]. Floros, C. (2008), Modelling Volatility using GARCH Models: Evidence from Egypt and Israel, Middle Eastern Finance and Economics Vol. 1, No.2, pp. 31-41.

[19]. Glosten, L., Jagannathan, R., et al. (1993), On the relation between expected return on stocks,, Journal of Finance, Vol. 48, pp. 1779-801.

[20]. Hamilton, Susmel., R., et al. (1994), Autoregressive Conditional Heteroskedasticity and Changes in Regime, Journal of Econometrics, Vol. 64, No.1-2, pp. 307-333.
[21]. Hammoudeh, S. and Li, H. (2006), Sudden changes in volatility in emerging markets: the case of Gulf Arab stock markets, International Review of Financial Analysis.

[22]. Inclan, C. and Tiao, G. C. (1994), Use of Cumulative Sums of Squares for Retrospective Detection of Changes of Variance, Journal of the American Statistical Association, Vol. 89, No. 427, pp. 913-923.

[23]. Lamoureux, C. G. and Latrapes, W. D. (1990), Persistence in Variance, Structural Change, and the GARCH Model, Journal of Business \& Economic Statistics, Vol. 8, No.2.

[24]. Long, V. T. (2008), Empirical Analysis Of Stock Return Volatility With Regime Change Using Garch Model: The Case Of Vietnam Stock Market, Working Paper Series.

[25]. Malik, Farooq, et al. (2005), Measuring Volatility Persistence in the Presence of Sudden Changes in the Variance of Canadian Stock Returns, Canadian Journal of Economics, Vol. 38, No.3, pp. 1037-1056.

[26]. Malik, F. and Hassan, S. A. (2004), Modeling Volatility In Sector Index Returns With Garch Models Using An Iterated Algorithm, Journal of Economics and Finance, Vol. 28, No.2, pp. 211-225.

\section{Trang 20}


[27]. Mandelbrot, B. (1963), The variation of certain speculative prices, Journal of Business, Vol. 36, pp. 394-419.

[28]. Nelson, D. B. (1991), Conditional Heteroskedasticity in Asset Returns: A New Approach, Econometrica, Vol. 59, No.2, pp. 323-70.

[29].Pagan, Adrian R., et al. (1989), Alternative Models for Conditional Stock Volatility, Working Paper Series.

[30].Poon, S.-H. and Taylor, S. J. (1992), Stock returns and volatility: An empirical study of the UK stock market, Journal of Banking and Finance, Vol. 16, pp. 37-59.

[31]. Poterba, J. M. and Summers, L. (1986), The Persistence of Volatility and Stock Market Fluctuations., American Economic Review, Vol. 76, pp. 11431151.

[32]. Susmel, R. (1997), Switching Volatility in Latin American Emerging Equity Markets, Working Paper.
[33]. Susmel, R. (2000), Switching Volatility in Private International Equity Markets, International Journal of Finance and Economics, Vol. 5, No.4, pp. 265-283.

[34]. Taylor, S. (1986), Modelling Financial Time Series, John Wiley \& Sons, New York.

[35]. Wang, P. and Moore, T. (2009), Sudden changes in volatility: The case of five central European stock markets, Journal of International Financail Markets, Institutions and Money, Vol. 19, No.1, pp. 33-46.

[36].Zakoian, J. M. (1994), Threshold heteroscedastic models, Journal of Economic Dynamics and Control, Vol. 18, pp. 931-955. 